Supporting Information for

\title{
Modeling Tryptophan/Indoleamine 2,3-Dioxygenase with Heme Superoxide Mimics: Is Ferryl the Key Intermediate?
}

Pritam Mondal ${ }^{\dagger}$ and Gayan B. Wijeratne ${ }^{*}, \dagger$

${ }^{\dagger}$ Department of Chemistry, University of Alabama at Birmingham, Birmingham, AL 35205, United States.

*To whom correspondence should be addressed:

Gayan B. Wijeratne

wijeratne@uab.edu 
Figure S1. UV-vis spectra for the formation of $\left[(\mathbf{B})(\mathbf{P o r}) \mathbf{F e}^{\mathrm{III}}\left(\mathbf{O}_{2}^{-\bullet}\right)\right]$ in 9:1 DCM:THF at $-80{ }^{\circ} \mathrm{C}$.

Figure S2. Resonance Raman data for $\left[(\mathbf{T H F})\left(\mathrm{F}_{20} \mathbf{T P P}\right) \mathrm{Fe}^{\mathrm{III}}\left(\mathbf{O}_{2^{--}}\right)\right]$and $\left[(\mathrm{Im})\left(\mathrm{F}_{20} \mathbf{T P P}\right) \mathrm{Fe}^{\mathrm{III}}\left(\mathbf{O}_{2}^{-}\right.\right.$

)].

Figure S3. UV-vis spectral changes (in 9:1 DCM:THF at $-40{ }^{\circ} \mathrm{C}$ ) for the reaction of

[(THF)(TMPP)Fe $\left.{ }^{\mathrm{III}}\left(\mathrm{O}_{2}^{-\bullet}\right)\right]$ and $\left[(\mathrm{Im})(\mathbf{T M P P}) \mathrm{Fe}^{\mathrm{III}}\left(\mathrm{O}_{2^{-*}}\right)\right]$ with 3-methylindole.

Figure S4. UV-vis spectral changes (in 9:1 DCM:THF at $-55^{\circ} \mathrm{C}$ ) for the reaction of $\left[(\mathbf{T H F})\left(\mathrm{F}_{20} \mathbf{T P P}\right) \mathrm{Fe}^{\mathrm{III}}\left(\mathbf{O}_{2}^{-*}\right)\right]$ and $\left[(\mathbf{I m})\left(\mathrm{F}_{20} \mathbf{T P P}\right) \mathrm{Fe}^{\mathrm{IIII}}\left(\mathbf{O}_{2}^{--}\right)\right]$with 3-methylindole.

Figure S5. UV-vis spectral changes (in 9:1 DCM:THF at $-40{ }^{\circ} \mathrm{C}$ ) for the reaction of $\left[(\mathbf{T H F})(\mathbf{T P P}) \mathbf{F e}^{\mathrm{III}}\left(\mathbf{O}_{2}^{-\cdot}\right)\right]$ and $\left[(\mathrm{Im})(\mathbf{T P P}) \mathbf{F e}^{\mathrm{III}}\left(\mathbf{O}_{2}^{--}\right)\right]$with 2,3-dimethylindole.

Figure S6. UV-vis spectral changes (in 9:1 DCM:THF at $-40{ }^{\circ} \mathrm{C}$ ) for the reaction of [(THF)(TPP)Fe $\left.\mathbf{F}^{\mathrm{III}}\left(\mathrm{O}_{2}^{--}\right)\right]$and $\left[(\mathbf{I m})(\mathbf{T P P}) \mathbf{F} \mathbf{e}^{\mathrm{III}}\left(\mathrm{O}_{2}^{--}\right)\right]$with $N$-acetyl-L-tryptophan methyl ester.

Figure S7. EPR spectral data (in frozen 9:1 DCM:THF at $7 \mathrm{~K}$ ) at different points during the reaction of [(THF)(TPP) $\left.\mathbf{F e}^{\mathrm{III}}\left(\mathrm{O}_{2}^{--}\right)\right]$with 3-methylindole.

Figure S8. UV-vis spectral changes (in 9:1 DCM:THF at $-40{ }^{\circ} \mathrm{C}$ ) for the self-decay of $\left[(\mathbf{T H F})(\mathbf{P o r}) \mathrm{Fe}^{\mathrm{III}}\left(\mathrm{O}_{2}^{--}\right)\right]$complexes.

Figure S9. UV-vis spectra (in 9:1 DCM:THF at $-40{ }^{\circ} \mathrm{C}$ ) of $\left[(\mathbf{P o r}) \mathrm{Fe}^{\mathrm{IV}}(\mathbf{O})\right]$ and $\left[(\mathbf{I m})(\mathbf{P o r}) \mathbf{F e}^{\mathrm{IV}}(\mathbf{O})\right]$ complexes.

Figure S10. UV-vis spectral changes (in 9:1 DCM:THF at $-40{ }^{\circ} \mathrm{C}$ ) for the reaction of [(THF)(TPP)Fe $\left.\mathbf{F}^{\mathrm{III}}\left(\mathrm{O}_{2}^{--}\right)\right]$and $\left[(\mathrm{Im})(\mathbf{T P P}) \mathrm{Fe}^{\mathrm{III}}\left(\mathrm{O}_{2}{ }^{-}\right)\right]$with $\mathrm{PPh}_{3}$ in presence of 3-methylindole.

Figure S11. ${ }^{31} \mathrm{P}$ NMR spectrum (in $\mathrm{CDCl}_{3}$ at $25{ }^{\circ} \mathrm{C}$ ) for the reaction mixture of [(THF)(TPP)Fe $\left.{ }^{\mathrm{III}}\left(\mathrm{O}_{2}^{-{ }^{-}}\right)\right]$and 3-methylindole in presence of $\mathrm{PPh}_{3}$.

Figure S12. ${ }^{31} \mathrm{P}$ NMR spectrum (in $\mathrm{CDCl}_{3}$ at $25{ }^{\circ} \mathrm{C}$ ) for the reaction mixture containing $\mathrm{PPh}_{3}$, [(THF)(TPP)Fe $\left.{ }^{\mathrm{II}}\right]$ and 3-methylindole. (without $\mathrm{O}_{2(\mathrm{~g})}$ ).

Figure $\mathrm{S} 13 .{ }^{31} \mathrm{P}$ NMR spectrum (in $\mathrm{CDCl}_{3}$ at $25{ }^{\circ} \mathrm{C}$ ) for the reaction mixture containing $\mathrm{PPh}_{3}, 3$ -

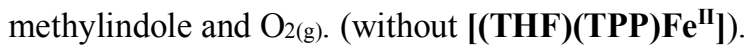

Figure S14. ${ }^{31} \mathrm{P}$ NMR spectrum (in $\mathrm{CDCl}_{3}$ at $25{ }^{\circ} \mathrm{C}$ ) for the reaction mixture containing $\mathrm{PPh}_{3}$ and [(THF)(TPP)Fe $\left.{ }^{\mathrm{III}}\left(\mathrm{O}_{2}^{--}\right)\right]$.

Figure $\mathrm{S} 15 .{ }^{1} \mathrm{H}$ NMR spectrum (in $\mathrm{CDCl}_{3}$ at $25^{\circ} \mathrm{C}$ ) of $\mathbf{2 a}$.

Figure S16. ${ }^{1} \mathrm{H}$ NMR spectrum (in $\mathrm{CDCl}_{3}$ at $25^{\circ} \mathrm{C}$ ) of $\mathbf{2 b}$.

Figure S17. ${ }^{1} \mathrm{H}$ NMR spectrum (in $\mathrm{CDCl}_{3}$ at $25^{\circ} \mathrm{C}$ ) of $\mathbf{2 c}$.

Figure S18. LC-MS data for $2 \mathbf{c}\left({ }^{18} \mathbf{O}\right.$-labeled).

Figure S19. LC-MS data for $2 \mathbf{c}$ (using mixture of ${ }^{16} \mathbf{O}_{2}$ and ${ }^{18} \mathbf{O}_{2}$ ).

Figure S20. FT-IR spectra for $2 \mathbf{c}$ and $\mathbf{2 c}\left({ }^{18} \mathrm{O}\right.$-labeled).

Figure S21. UV-Vis spectral changes in 9:1 DCM:THF at $-40{ }^{\circ} \mathrm{C}$, and kinetic time traces for the reaction [(B)(TPP)Fe $\left.\mathbf{F e}^{\mathrm{III}}\left(\mathbf{O}_{2}^{--}\right)\right]$and 3-methylindole.

Figure S22. UV-Vis spectral changes in 9:1 DCM:THF at $-40{ }^{\circ} \mathrm{C}$, for the reaction of $\left[\left\{(\mathbf{T P P}) \mathrm{Fe}^{\mathrm{III}}\right\}_{2}(\mu-\mathrm{O})\right]$ and (B) [(THF)(TPP)Fe $\left.{ }^{\mathrm{IV}}(\mathbf{O})\right]$ with 100 equiv of 3-methylindole.

Figure S23. UV-vis spectra (in 9:1 DCM:THF at $-40^{\circ} \mathrm{C}$ ) of final heme products and comparisons with authentic samples of $\left[\left\{(\mathbf{T P P}) \mathbf{F} \mathbf{e}^{\mathrm{III}}\right\}_{2}(\boldsymbol{\mu}-\mathbf{O})\right]$ and $\left[(\mathbf{I m})_{2}(\mathbf{T P P}) \mathbf{F e}^{\mathrm{III}}\right]^{+}$.

Figure S24. EPR spectra (in frozen 9:1 DCM:THF at 7 K) of the final heme products. 


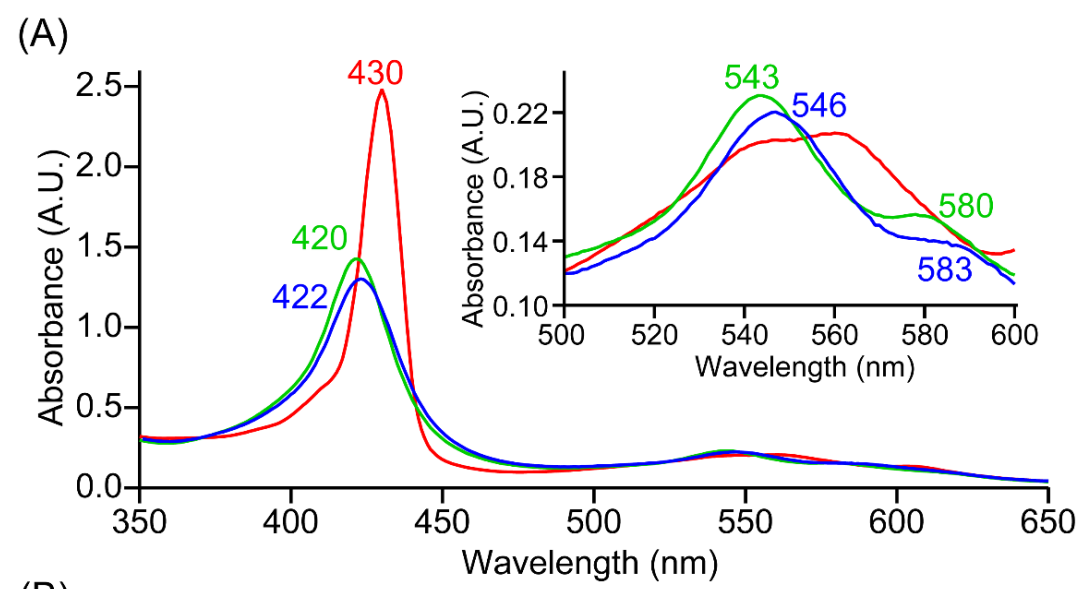

(B)

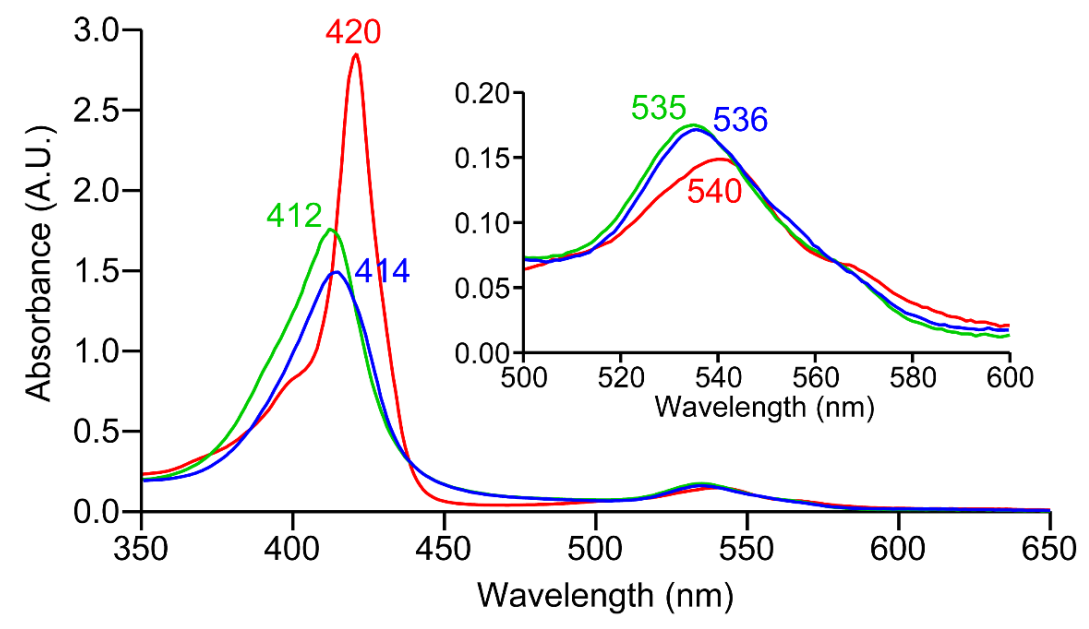

Figure S1. UV-vis spectra (in 9:1 DCM:THF at $-80{ }^{\circ} \mathrm{C}$ ) for the formation of $10 \mu \mathrm{M}$ (A)

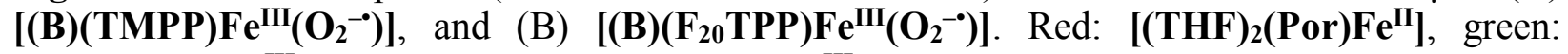
[(THF)(Por)Fe $\left.{ }^{\mathrm{III}}\left(\mathbf{O}_{2}^{-\cdot}\right)\right]$, and blue: $\left[(\mathbf{I m})(\right.$ Por $\left.) \mathbf{F e}^{\mathrm{III}}\left(\mathbf{O}_{2}^{-\bullet}\right)\right]$. Insets show the expanded Q-band regions. 

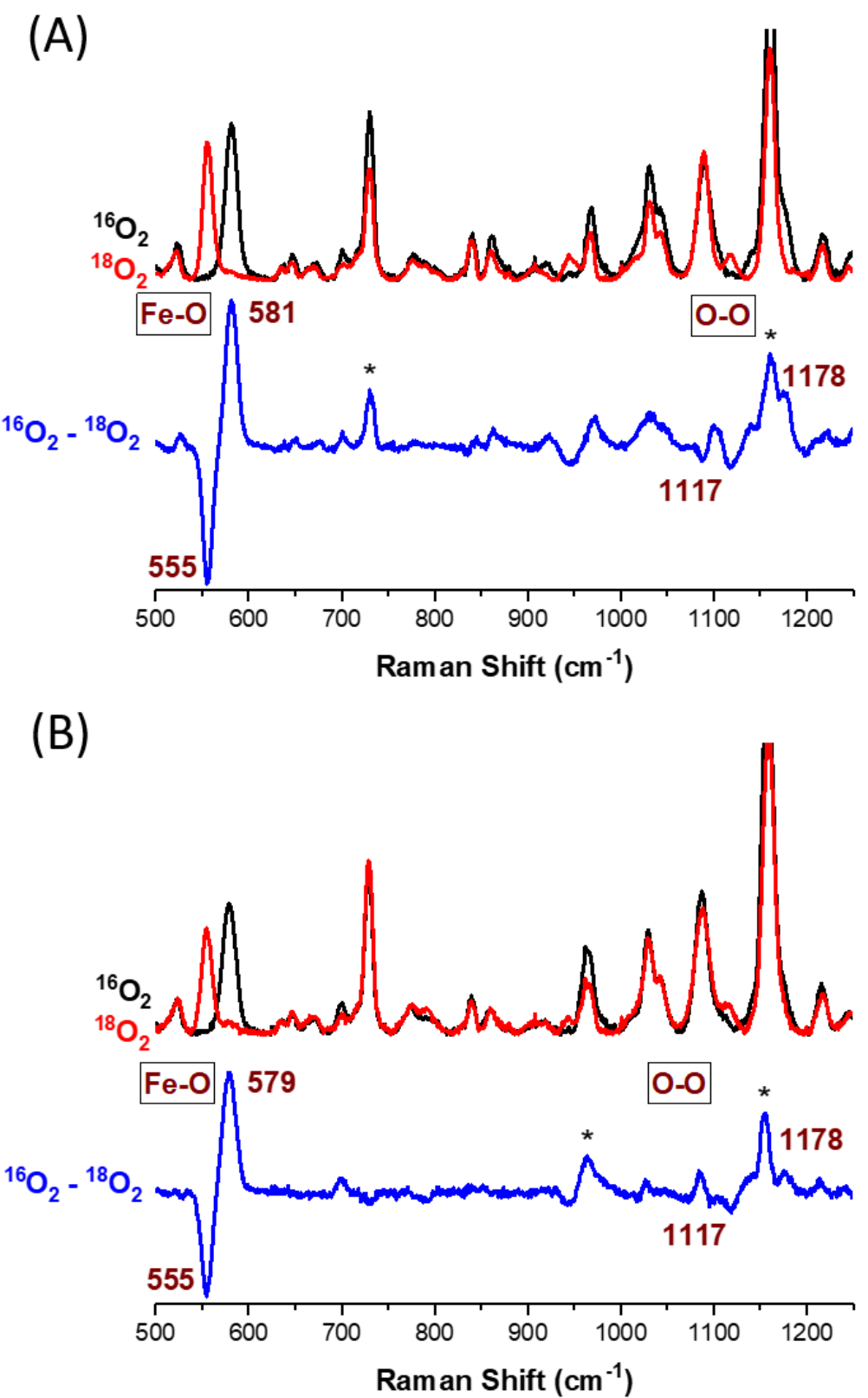

Figure S2. Resonance Raman spectral data $\left(\lambda_{\text {ex }}=406.7 \mathrm{~nm}\right)$ for $\left.(\mathrm{A})\left[(\mathbf{T H F})\left(\mathbf{F}_{20} \mathbf{T P P}\right) \mathbf{F e}^{\mathrm{III}}\left(\mathbf{O}_{\mathbf{2}^{-}}\right)^{-}\right)\right]$ $\left(v(\mathrm{Fe}-\mathrm{O}): 581\left(\Delta^{18} \mathrm{O}_{2}=-26\right)\right.$ and $\left.v(\mathrm{O}-\mathrm{O}): 1178\left(\Delta^{18} \mathrm{O}_{2}=-61\right) \mathrm{cm}^{-1}\right)$ and (B) $\left[(\mathbf{I m})\left(\mathbf{F}_{20} \mathbf{T P P}\right) \mathbf{F e}^{\mathrm{III}}\left(\mathbf{O}_{2}^{-{ }^{-}}\right)\right]\left(v(\mathrm{Fe}-\mathrm{O}): 579\left(\Delta^{18} \mathrm{O}_{2}=-24\right)\right.$ and $\left.v(\mathrm{O}-\mathrm{O}): 1178\left(\Delta^{18} \mathrm{O}_{2}=-61\right) \mathrm{cm}^{-1}\right)$ in frozen 9:1 DCM:THF (2 mM) prepared with ${ }^{16} \mathrm{O}_{2(\mathrm{~g})}$ (black) and ${ }^{18} \mathrm{O}_{2(\mathrm{~g})}$ (red). The difference spectra are shown in blue. (*due to subtraction of intense heme bands). Note: The exact assignments of the additional isotope sensitive features require much rigorous spectroscopic and computational analyses (i.e., normal coordinate analysis). 

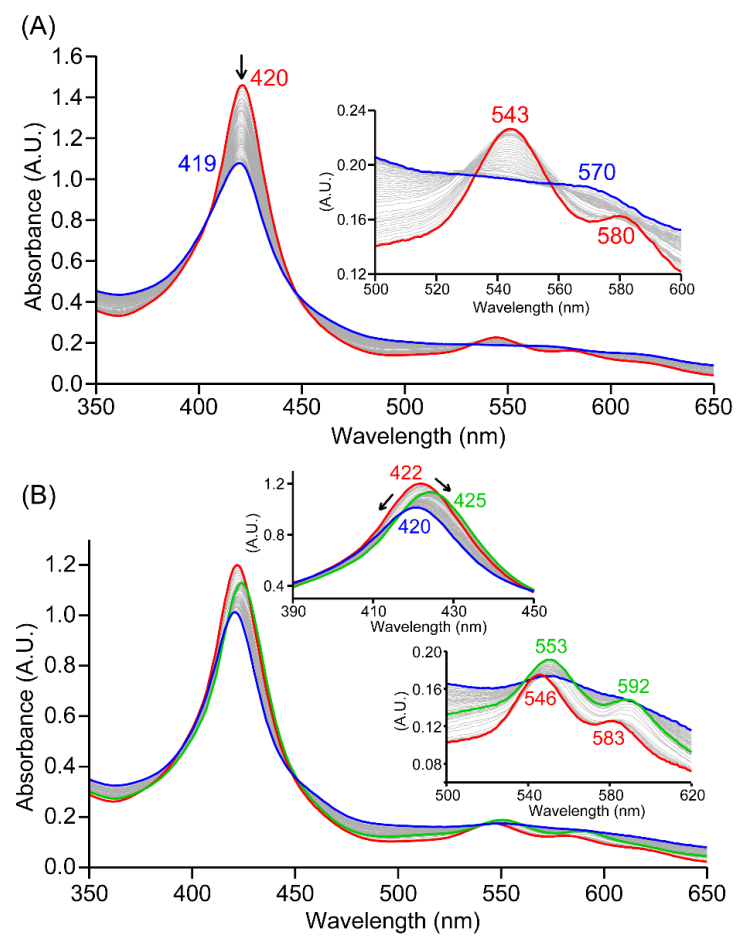

Figure S3. UV-vis spectral changes (in 9:1 DCM:THF at $-40{ }^{\circ} \mathrm{C}$ ) observed during the reaction of $10 \mu \mathrm{M}$ (A) [(THF)(TMPP)Fe $\left.\mathbf{F e}^{\mathrm{III}}\left(\mathbf{O}_{2}^{-{ }^{-}}\right)\right]$and (B) $\left[(\mathbf{I m})(\mathbf{T M P P}) \mathbf{F e}^{\mathrm{III}}\left(\mathbf{O}_{2}^{-{ }^{-}}\right)\right]$with 100 equiv of 3-methylindole. (Red = initial ferric superoxo complex; green $=$ intermediate species; blue $=$ final heme product). Inset shows the expanded Soret band and $\mathrm{Q}$ band regions, and arrows indicate the direction of peak transition.
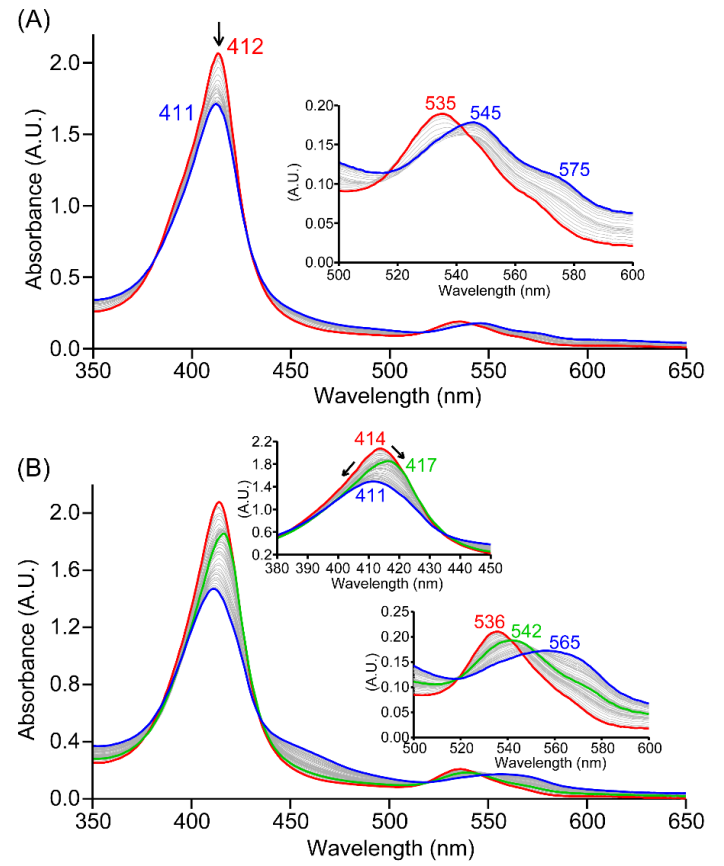

Figure S4. UV-vis spectral changes (in 9:1 DCM:THF at $-55^{\circ} \mathrm{C}$ ) observed during the reaction of $10 \mu \mathrm{M}$ (A) [(THF)(F $\left.\left.\mathbf{F}_{20} \mathbf{T P P}\right) \mathbf{F e}^{\mathrm{III}}\left(\mathbf{O}_{2}^{-{ }^{-}}\right)\right]$and (B) $\left[(\mathbf{I m})\left(\mathbf{F}_{20} \mathbf{T P P}\right) \mathbf{F e}^{\mathrm{III}}\left(\mathbf{O}_{2}^{-{ }^{-}}\right)\right]$with 100 equiv of 3-methylindole. (Red $=$ initial ferric superoxo complex; green $=$ intermediate species; blue $=$ final heme product). Inset shows the expanded Soret band and Q band regions, and arrows indicate the direction of peak transition. 

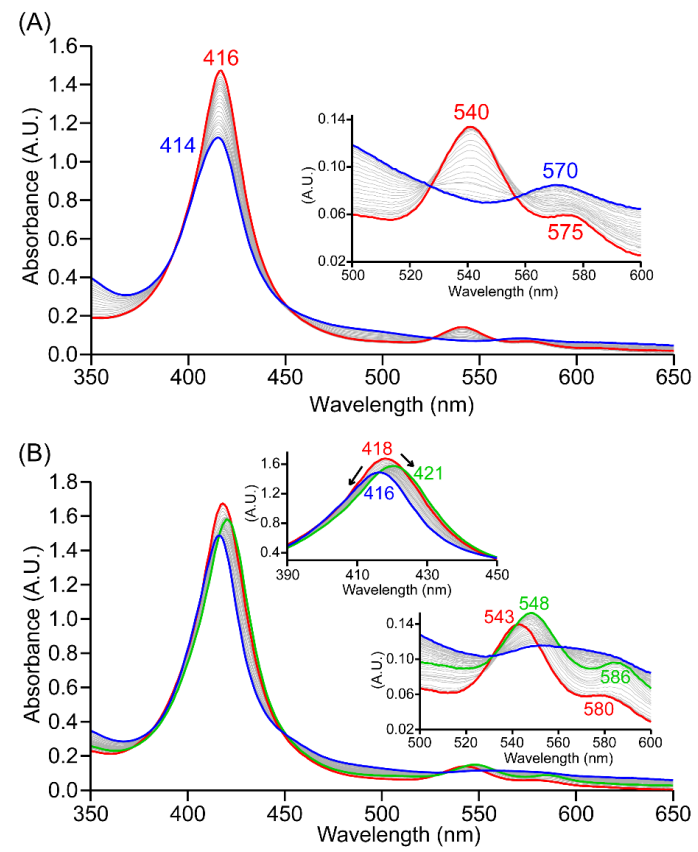

Figure S5. UV-vis spectral changes (in 9:1 DCM:THF at $-40{ }^{\circ} \mathrm{C}$ ) observed during the reaction of $10 \mu \mathrm{M}$ (A) [(THF)(TPP)Fe $\left.\mathbf{F e}^{\mathrm{III}}\left(\mathbf{O}_{2}^{-\cdot}\right)\right]$ and (B) $\left[(\mathbf{I m})(\mathbf{T P P}) \mathbf{F e} \mathrm{e}^{\mathrm{III}}\left(\mathbf{O}_{2}^{-{ }^{-*}}\right)\right]$ with 100 equiv of 2,3-dimethylindole. (Red $=$ initial ferric superoxo complex; green $=$ intermediate species; blue $=$ final heme product). Inset shows the expanded Soret band and $\mathrm{Q}$ band regions, and arrows indicate the direction of peak transition.
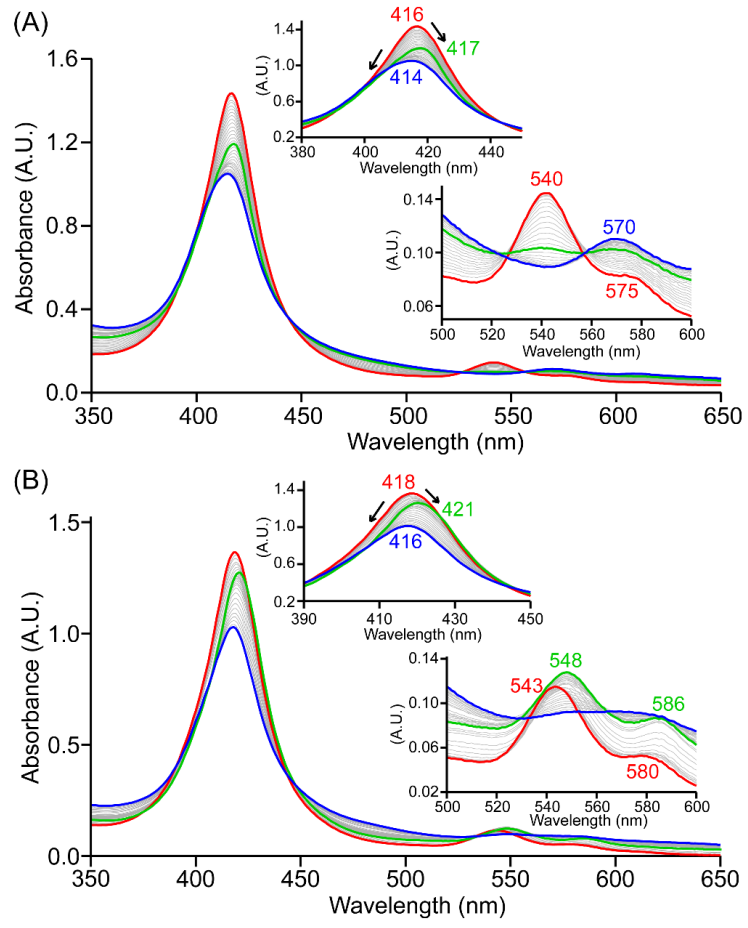

Figure S6. UV-vis spectral changes (in 9:1 DCM:THF at $-40{ }^{\circ} \mathrm{C}$ ) observed during the reaction of $10 \mu \mathrm{M}$ (A) $\left[(\mathbf{T H F})(\mathbf{T P P}) \mathrm{Fe}^{\mathrm{III}}\left(\mathbf{O}_{2}^{-{ }^{-}}\right)\right]$and (B) $\left[(\mathbf{I m})(\mathbf{T P P}) \mathbf{F e}^{\mathrm{III}}\left(\mathbf{O}_{2}^{-{ }^{-}}\right)\right]$with 100 equiv of $N$-acetyl-L-tryptophan methyl ester. (Red = initial ferric superoxo complex; green = intermediate species; blue = final ferric product). Inset shows the expanded Soret band and Q band regions; arrows indicate the direction of peak transition. 


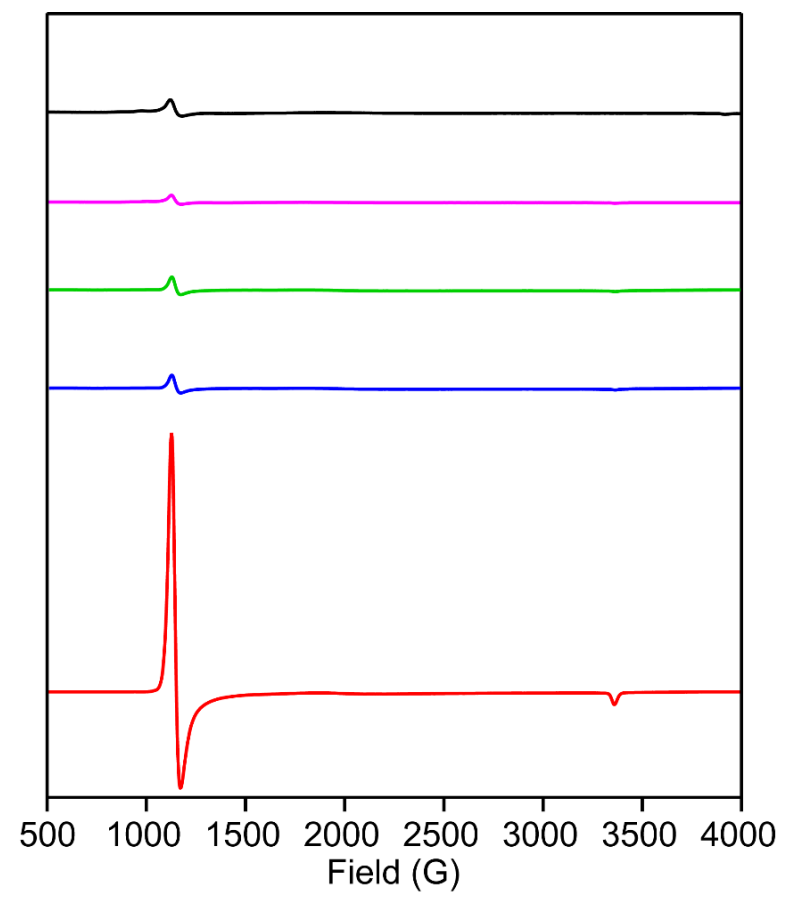

Figure S7. EPR spectral features (in frozen 9:1 DCM:THF at $7 \mathrm{~K}$ ) at different time points during the reaction of $2 \mathrm{mM}$ [(THF)(TPP)Fe $\mathbf{e}^{\mathrm{III}}\left(\mathbf{O}_{2^{-}}^{-\mathbf{T}^{-}}\right)$] with 100 equiv of 3-methylindole in comparison with the highspin $\mathrm{Fe}^{\mathrm{III}}$ features of a frozen $2 \mathrm{mM}$ 9:1 DCM:THF solution of [(TPP)Fe $\left.{ }^{\mathrm{III}} \mathbf{C l}\right]$ (red); $\mathrm{g}_{\perp}=5.9, \mathrm{~g}_{\|}=2.0$. [(THF)(TPP)Fe $\left.{ }^{\mathrm{III}}\left(\mathbf{O}_{2}^{-{ }^{-}}\right)\right]$(blue), [(THF)(TPP)Fe $\left.{ }^{\mathrm{III}}\left(\mathbf{O}_{2}^{-{ }^{-}}\right)\right]+3$-methylindole immediate (green), putative ferryl reaction intermediate (pink) and final product (black). 

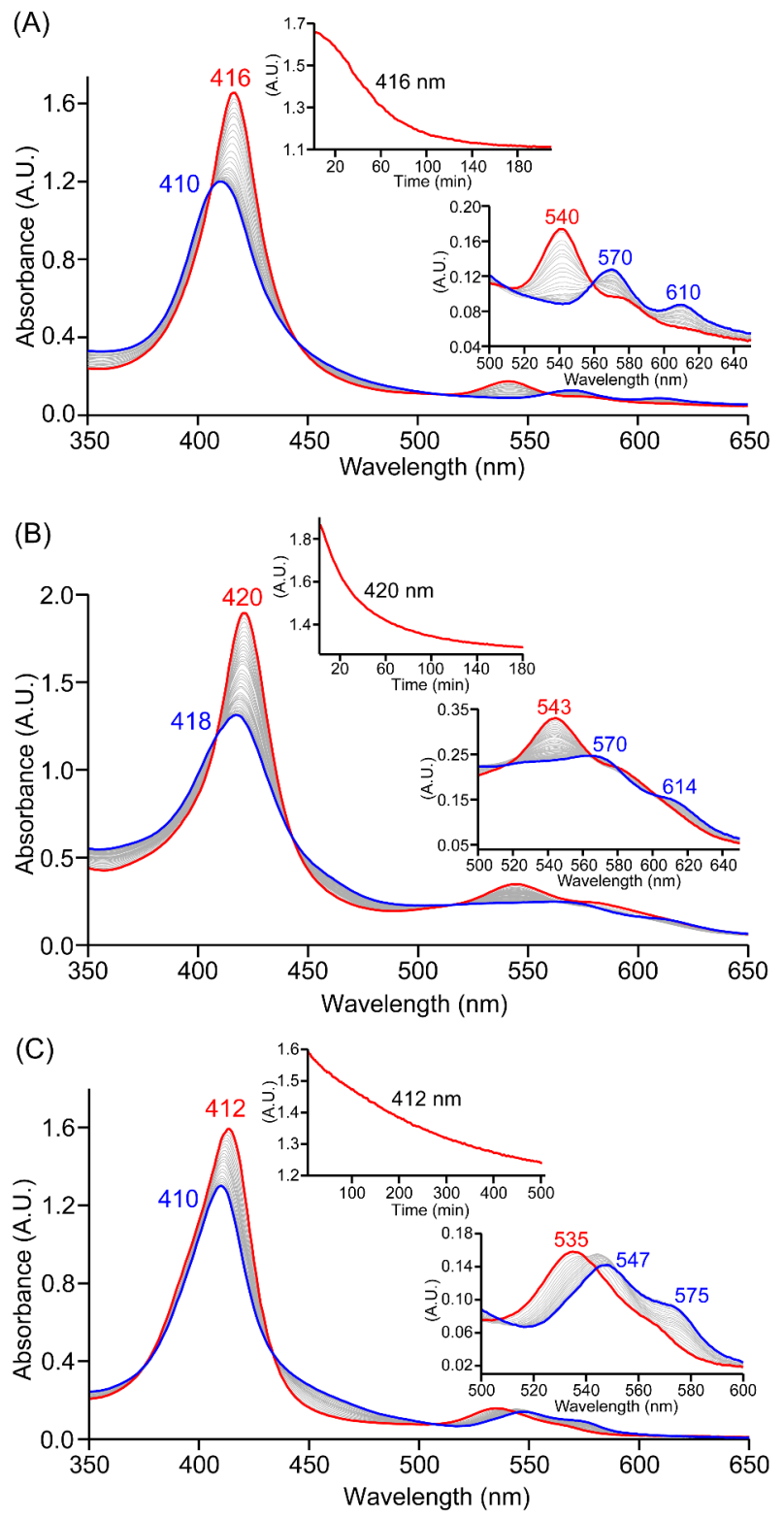

Figure S8. UV-vis spectral changes (in 9:1 DCM:THF at $-40^{\circ} \mathrm{C}$ ) of the self-decay of $10 \mu \mathrm{M}$ (A)

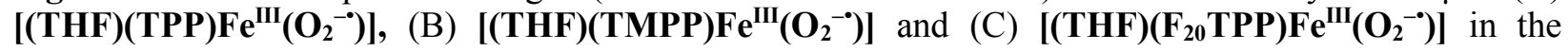
absence of any substrates. Insets show the expanded Q-band regions, and progression of Soret band changes centered at (A) 416, (B) 420, and (C) $412 \mathrm{~nm}$. 

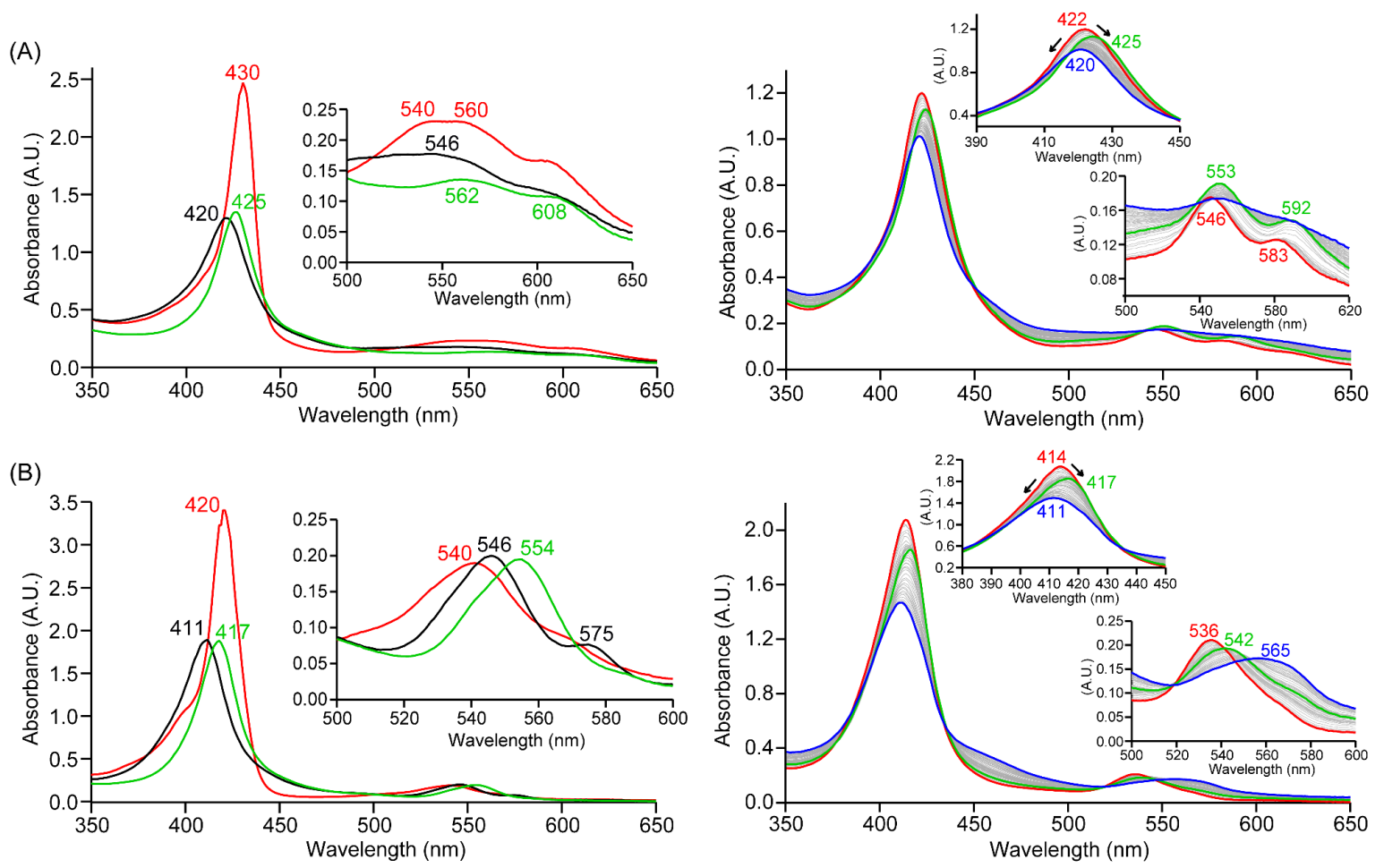

Figure S9. Left: UV-vis spectra (in 9:1 DCM:THF at $-40^{\circ} \mathrm{C}$ ) of $10 \mu \mathrm{M}\left[(\mathbf{T H F})_{2}(\mathbf{P o r}) \mathrm{Fe}^{\mathrm{II}}\right]$ (red), $\left[(\mathbf{P o r}) \mathbf{F e}^{\mathrm{IV}}(\mathbf{O})\right]$ (black) and $\left[(\mathbf{I m})(\mathbf{P o r}) \mathbf{F e}^{\mathrm{IV}}(\mathbf{O})\right]$ (green) for (A) TMPP and (B) $\mathrm{F}_{20} \mathrm{TPP}$ porphyrinates (insets show the expanded Q-band regions); Right: UV-vis spectral changes during the reaction of $10 \mu \mathrm{M}$ (A) $\left[(\mathbf{I m})(\mathbf{T M P P}) \mathbf{F} \mathrm{e}^{\mathrm{III}}\left(\mathbf{O}_{2}^{--}\right)\right]$, (B) $\left[(\mathbf{I m})\left(\mathbf{F}_{20} \mathbf{T P P}\right) \mathbf{F e}^{\mathrm{III}}\left(\mathbf{O}_{2}{ }^{-0}\right)\right]$ with 100 equiv of 3-methylindole (red = initial ferric superoxo complex; green = intermediate species; blue = final heme product). Insets show the expanded Soret band and $\mathrm{Q}$ band regions, and arrows indicate the direction of peak transition. 

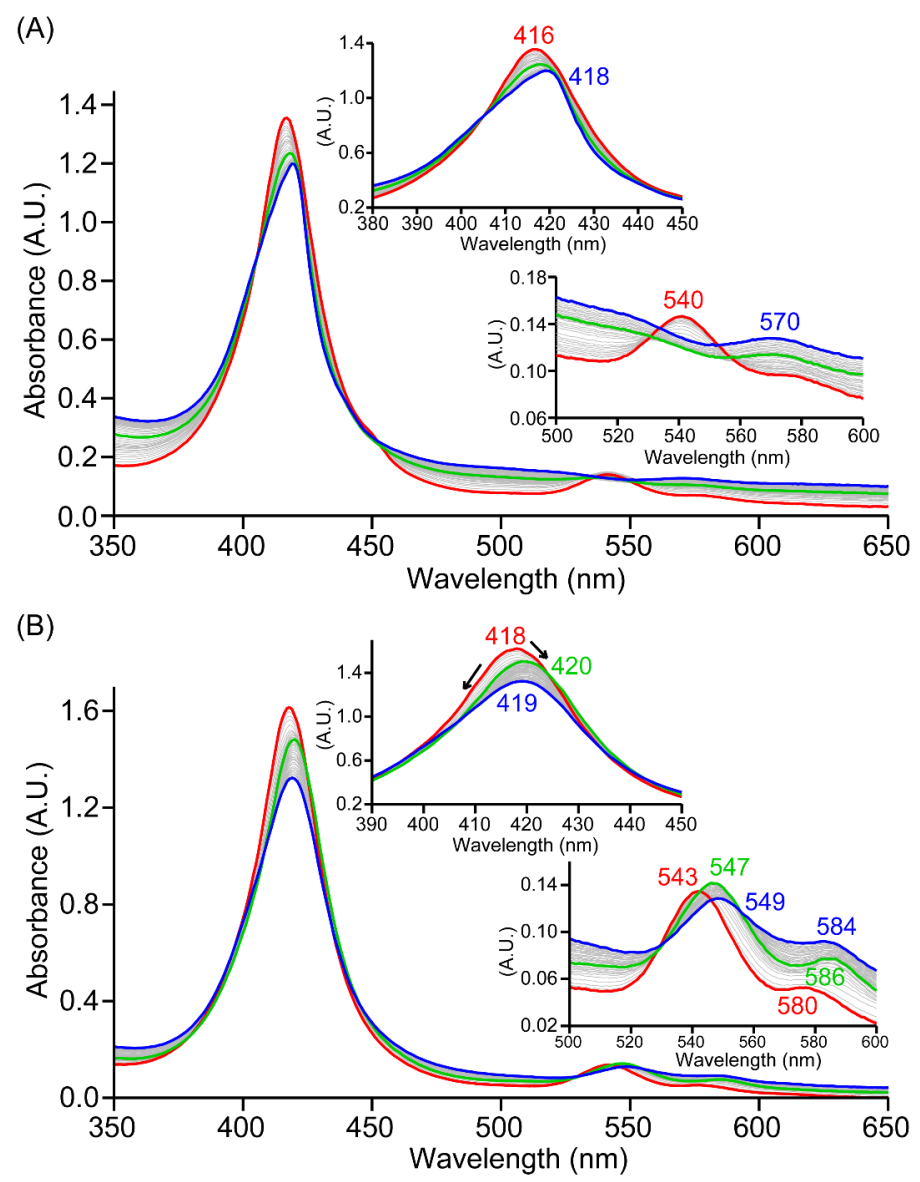

Figure S10. UV-vis spectral changes (in 9:1 DCM:THF at $-40{ }^{\circ} \mathrm{C}$ ) observed during the reaction of $10 \mu \mathrm{M}(\mathrm{A})\left[(\mathbf{T H F})(\mathbf{T P P}) \mathbf{F e}^{\mathrm{III}}\left(\mathbf{O}_{2^{-}}\right)\right]$and (B) $\left[(\mathbf{I m})(\mathbf{T P P}) \mathbf{F e}^{\mathrm{III}}\left(\mathbf{O}_{2^{-*}}\right)\right]$ with 100 equiv of 3methylindole in presence of 100 equiv of $\mathrm{PPh}_{3}$. $(\mathrm{Red}=$ initial ferric superoxo complex; green $=$ intermediate species; blue = final ferric product). Inset shows the expanded Soret band and Q band regions and arrows indicate the direction of peak transition. 


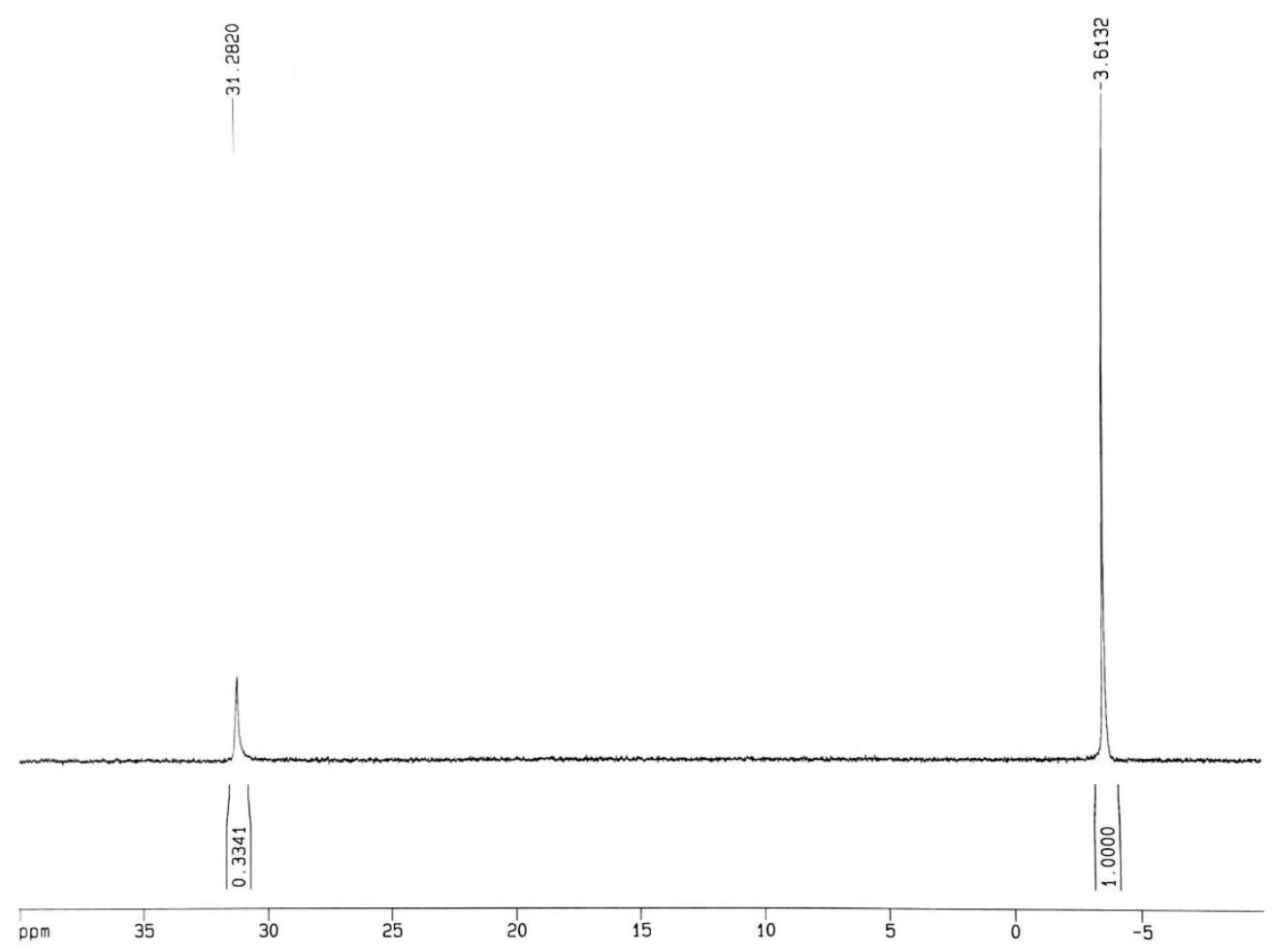

Figure S11. ${ }^{31} \mathrm{P}$ NMR spectrum (in $\mathrm{CDCl}_{3}$ at $25{ }^{\circ} \mathrm{C}$ ) indicating the oxidation of $\mathrm{PPh}_{3}$ during the reaction between $\left[(\mathbf{T H F})(\mathbf{T P P}) \mathbf{F e}^{\mathrm{III}}\left(\mathbf{O}_{2}^{-{ }^{-}}\right)\right]$and 3-methylindole.

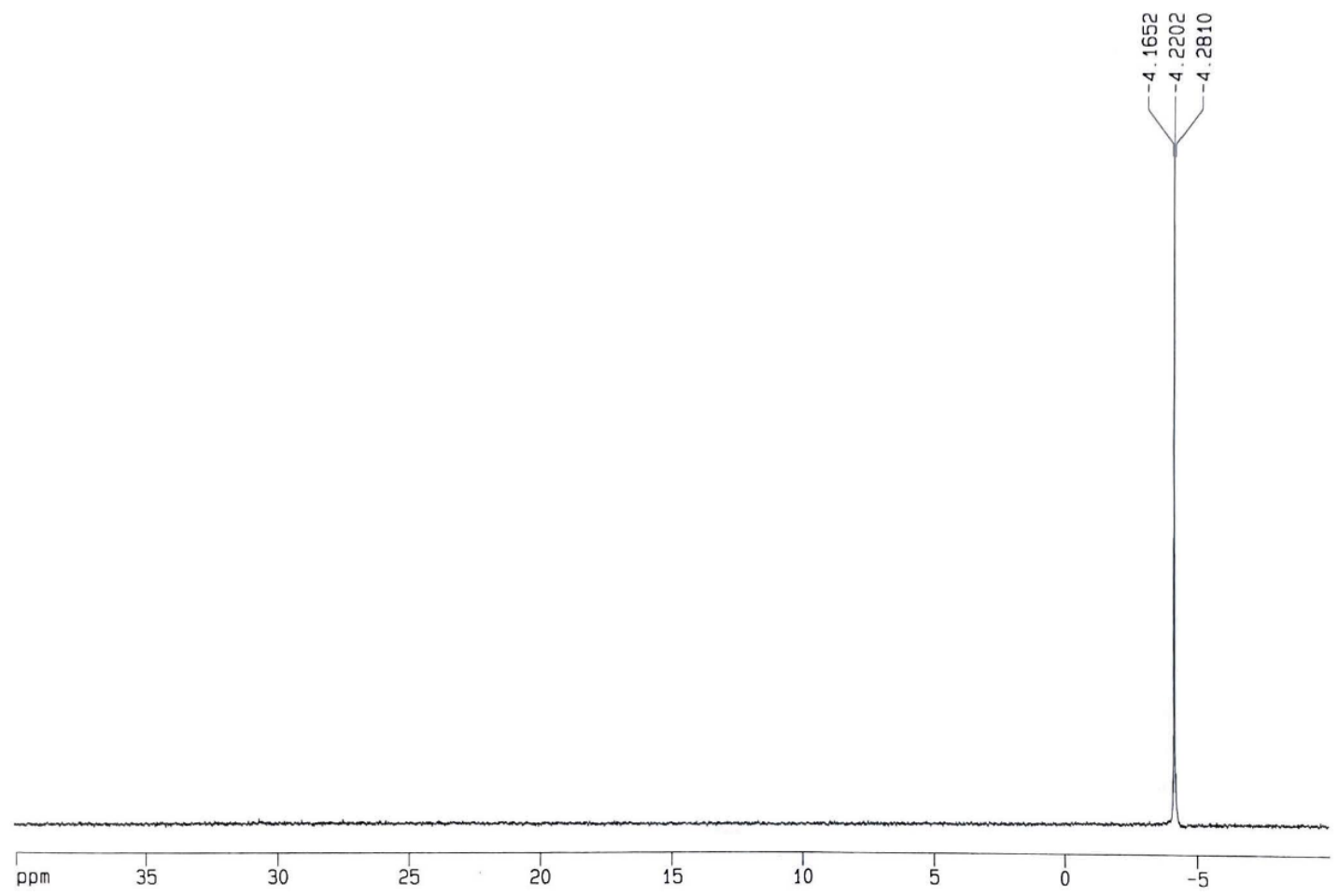

Figure S12. ${ }^{31} \mathrm{P}$ NMR spectrum (in $\mathrm{CDCl}_{3}$ at $25{ }^{\circ} \mathrm{C}$ ) of the control reaction mixture containing [(THF)(TPP)Fe $\left.{ }^{\mathrm{II}}\right], \mathrm{PPh}_{3}$ and 3-methylindole but not $\mathrm{O}_{2(\mathrm{~g}) \text {. }}$ 


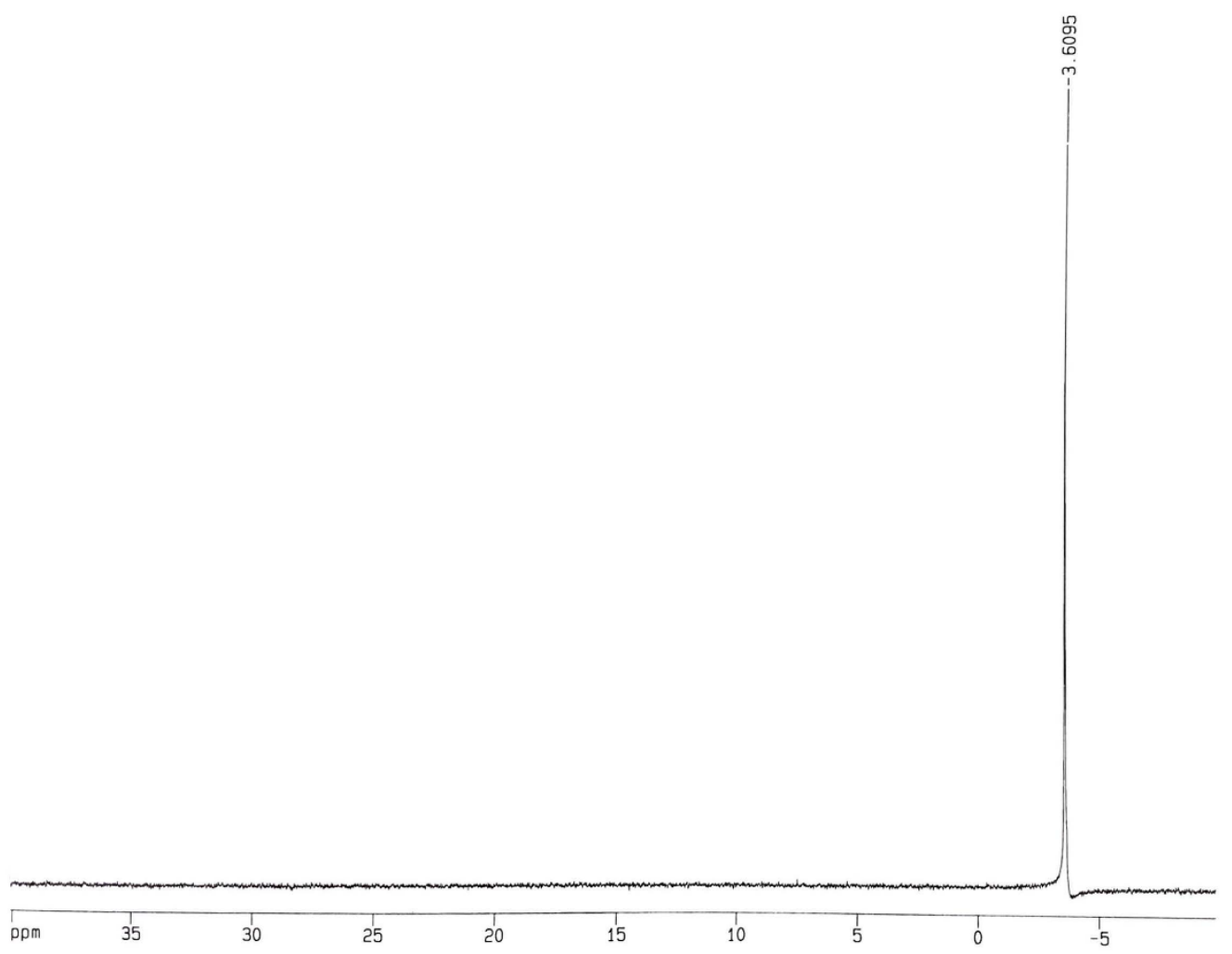

Figure S13. ${ }^{31} \mathrm{P}$ NMR spectrum (in $\mathrm{CDCl}_{3}$ at $25{ }^{\circ} \mathrm{C}$ ) of the control reaction mixture containing $\mathrm{PPh}_{3}, 3$-methylindole and $\mathrm{O}_{2(\mathrm{~g})}$, but not [(THF)(TPP)Fe $\left.{ }^{\mathrm{II}}\right]$.

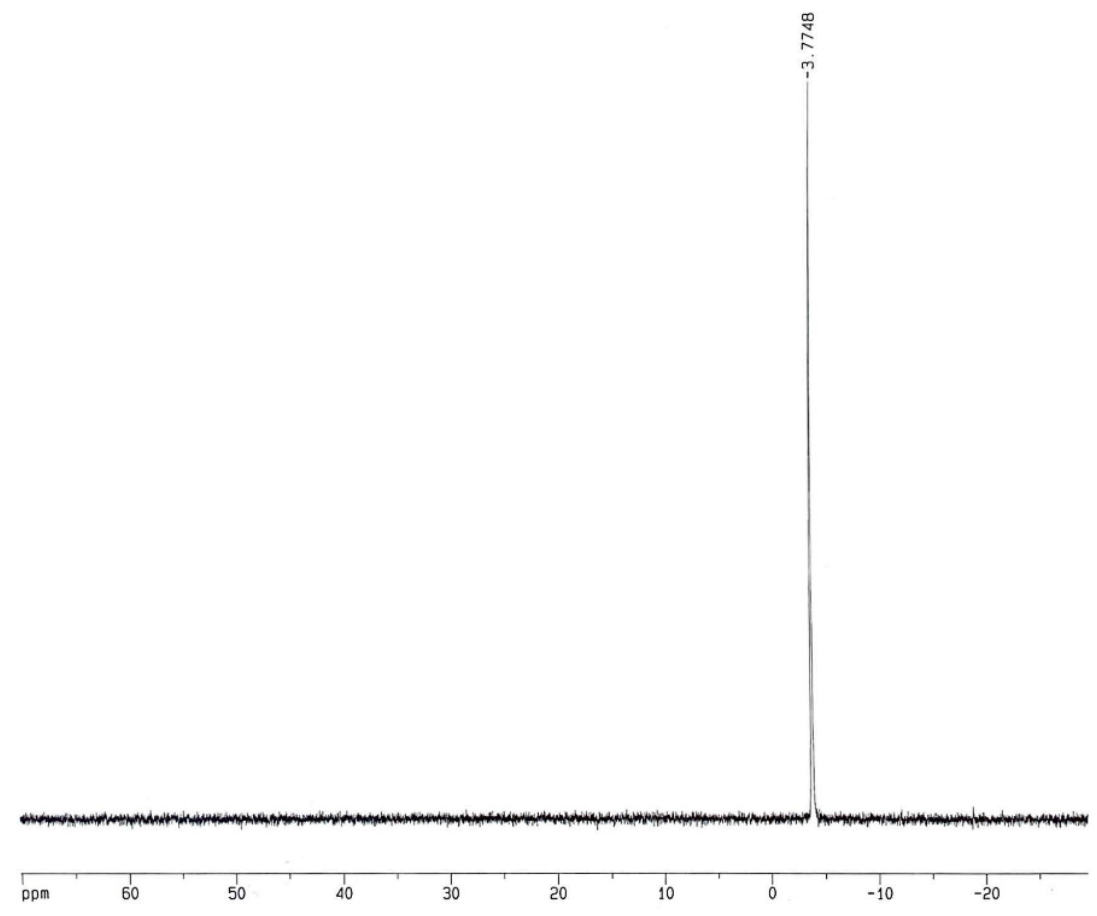

Figure S14. ${ }^{31} \mathrm{P}$ NMR spectrum (in $\mathrm{CDCl}_{3}$ at $25{ }^{\circ} \mathrm{C}$ ) of the control reaction mixture containing $\mathrm{PPh}_{3}$ and [(THF)(TPP)Fe $\left.{ }^{\mathrm{III}}\left(\mathbf{O}_{2}^{-\bullet}\right)\right]$. 


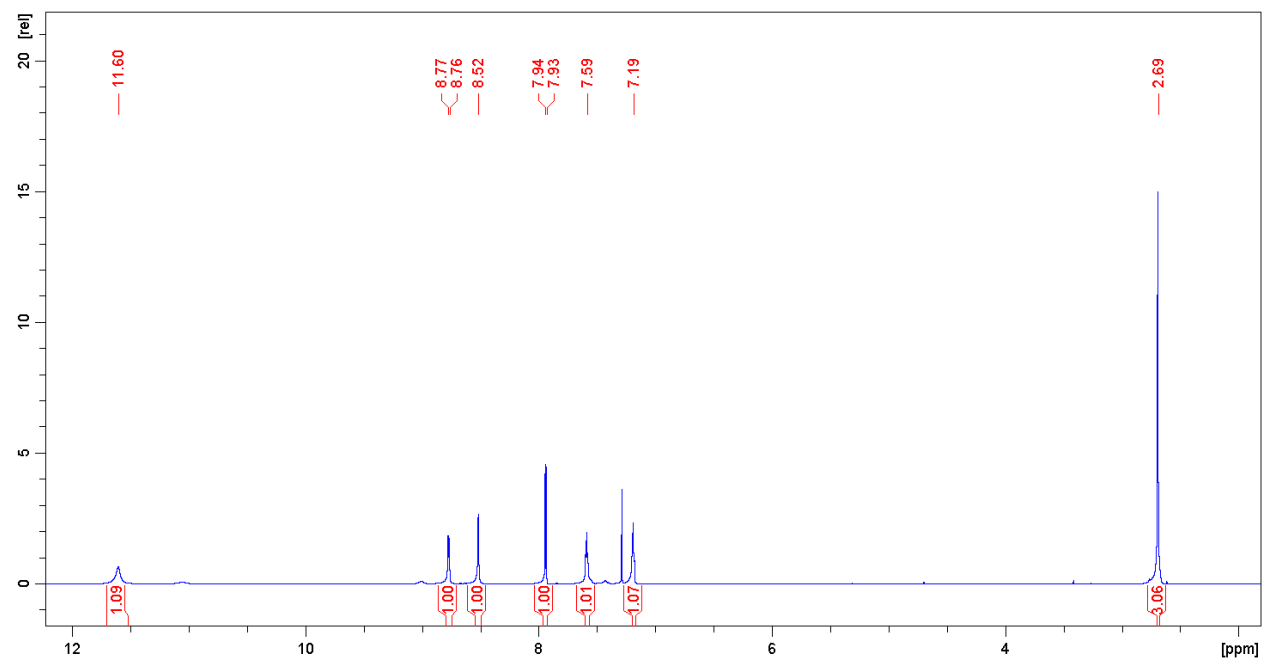

Figure S15. ${ }^{1} \mathrm{H}$ NMR spectrum (in $\mathrm{CDCl}_{3}$ at $25^{\circ} \mathrm{C}$ ) of $\mathbf{2 a}$.

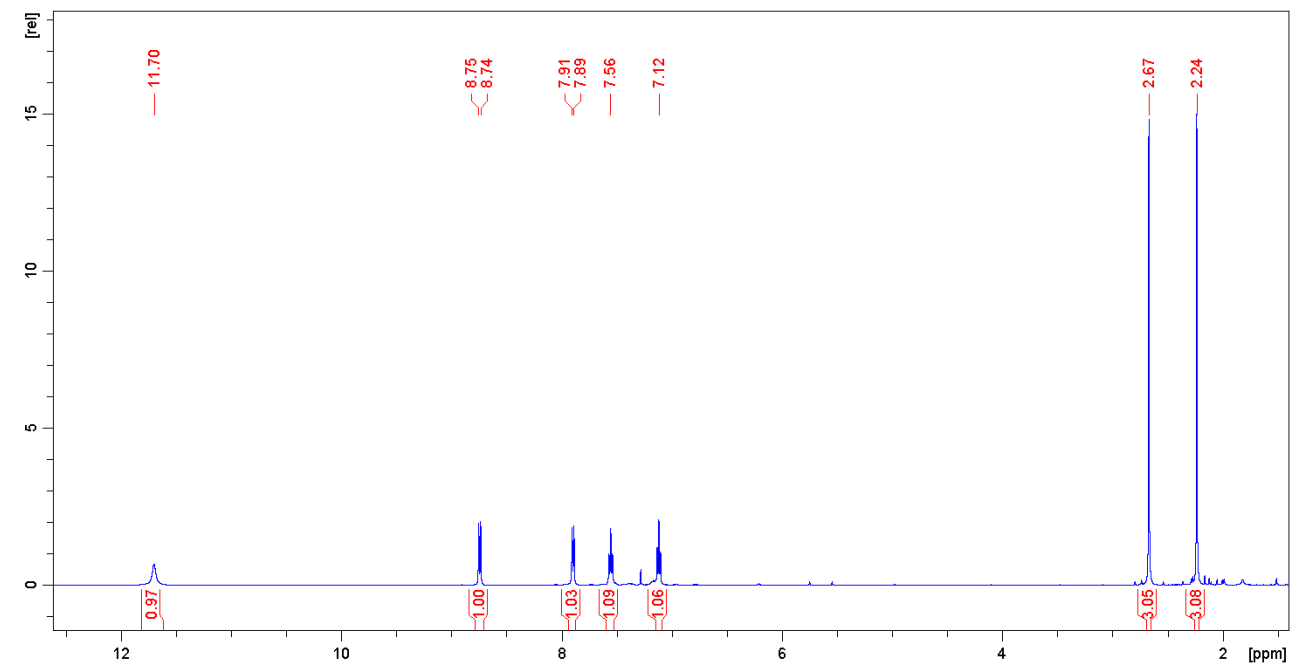

Figure S16. ${ }^{1} \mathrm{H} \mathrm{NMR}$ spectrum (in $\mathrm{CDCl}_{3}$ at $25^{\circ} \mathrm{C}$ ) of $\mathbf{2 b}$.

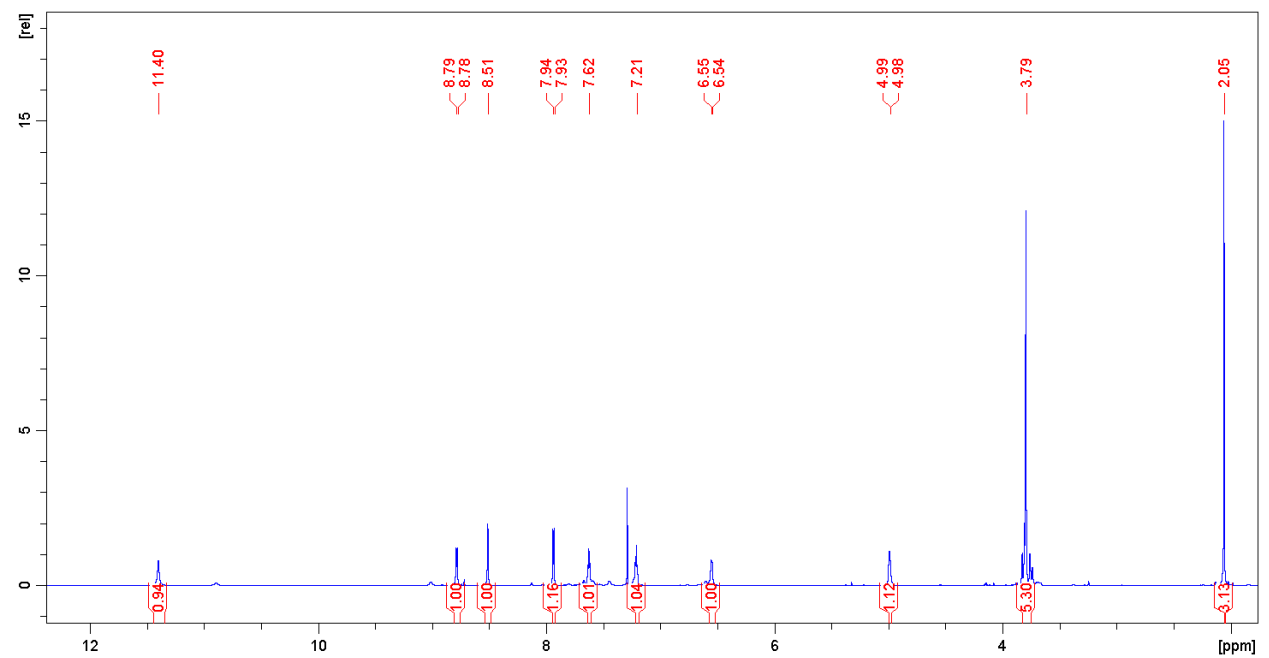

Figure S17. ${ }^{1} \mathrm{H}$ NMR spectrum (in $\mathrm{CDCl}_{3}$ at $25^{\circ} \mathrm{C}$ ) of $\mathbf{2 c}$. 


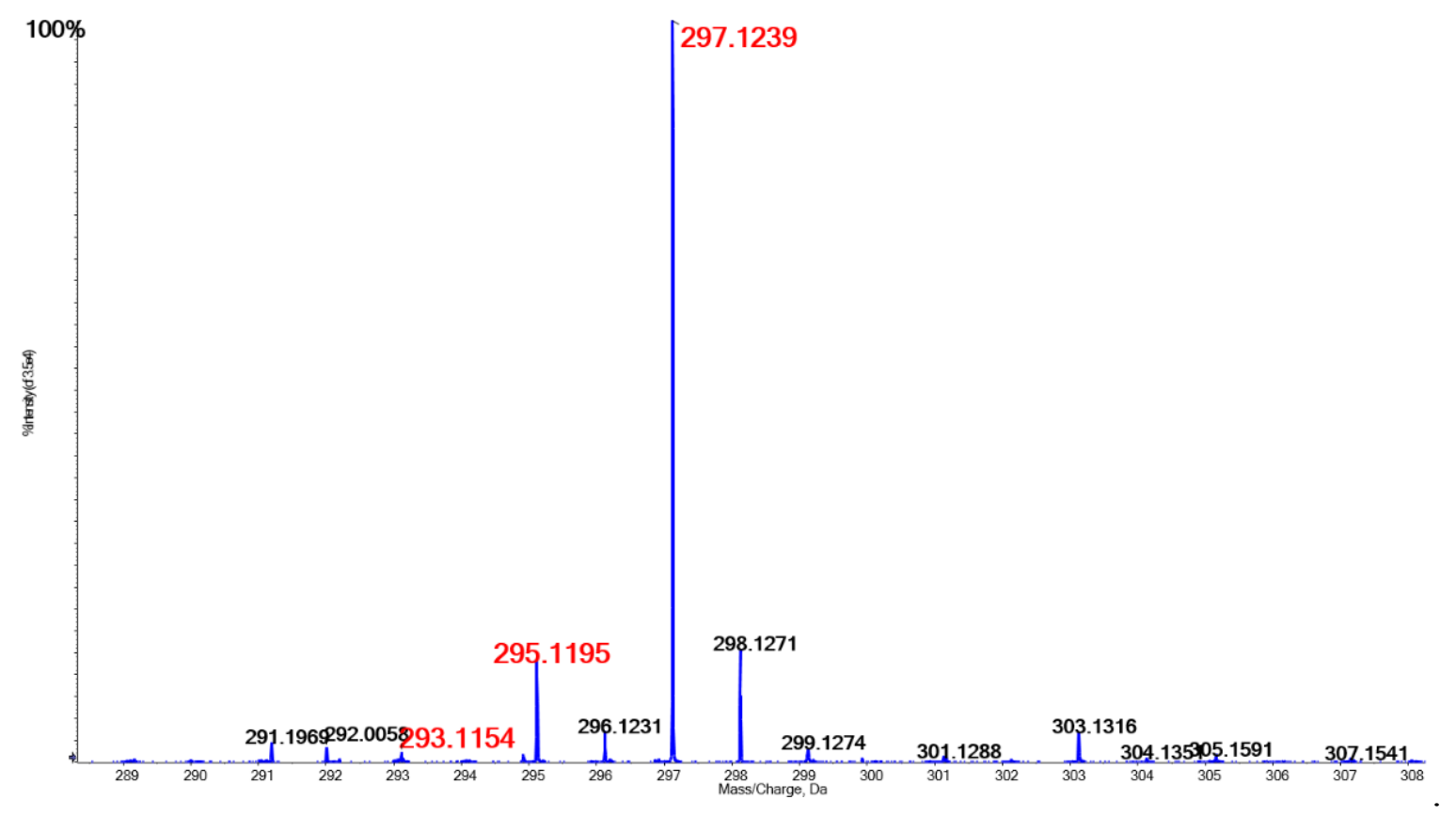

Figure S18. LC-MS spectrum of $2 \mathbf{c}\left({ }^{18} \mathbf{O}\right.$-labeled) showing $[\mathrm{M}+\mathrm{H}]^{+} m / z=297.12$ (calc. 297.12).

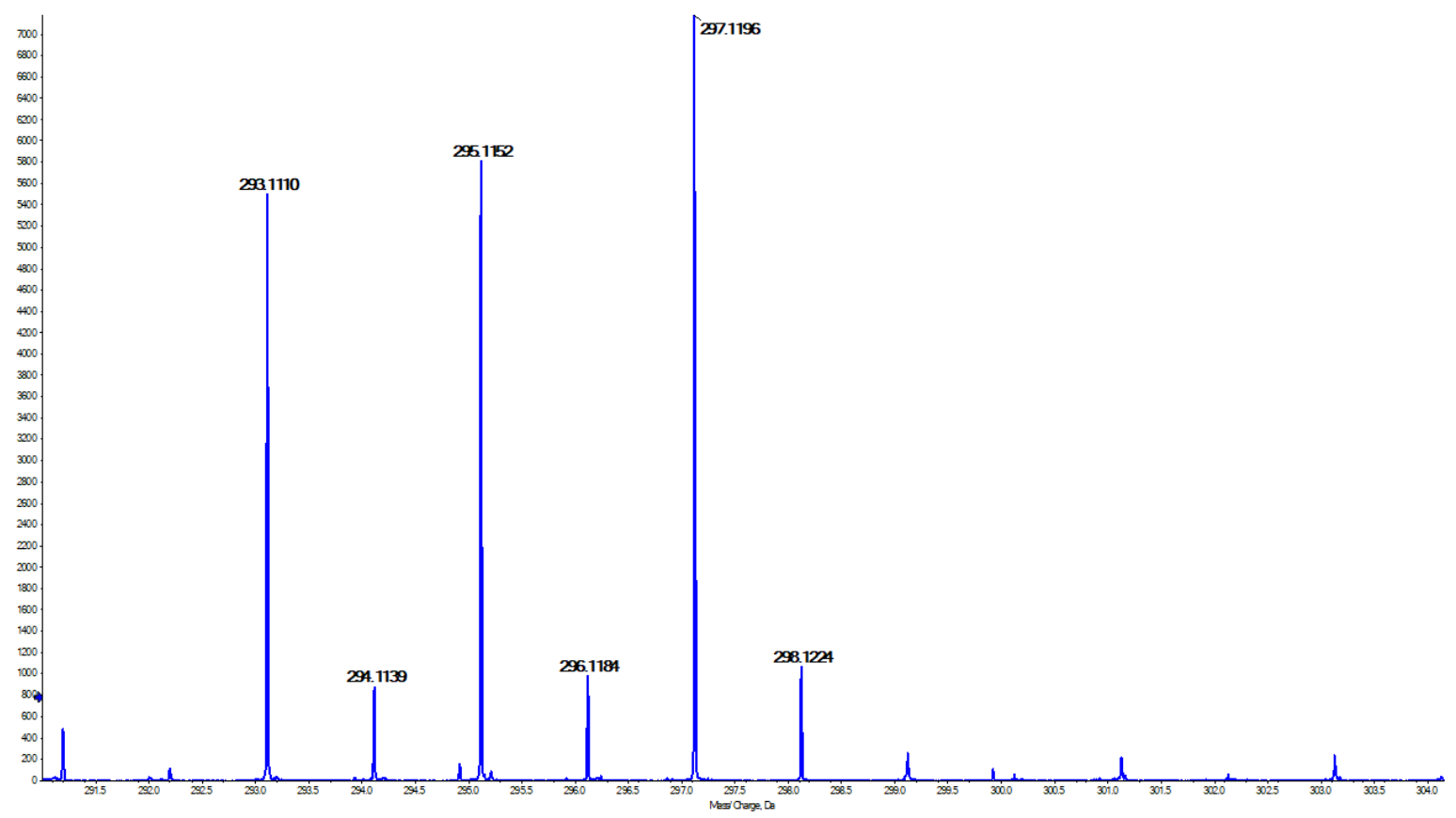

Figure S19. LC-MS spectrum of 2c (using a 1:1 mixture of ${ }^{16} \mathrm{O}_{2(\mathrm{~g})}$ and ${ }^{18} \mathrm{O}_{2(\mathrm{~g})}$ ) showing $[\mathrm{M}+\mathrm{H}]^{+}$ $m / z=293.11$ for $2 c\left(2^{16} \mathrm{O}\right)$ (calc. 293.11), $\mathrm{m} / \mathrm{z}=295.11$ for $2 \mathrm{c}\left({ }^{16} \mathrm{O}^{18} \mathrm{O}\right)$ (calc. 295.11), and $\mathrm{m} / \mathrm{z}=$ 297.119 for $2 \mathrm{c}\left(2^{18} \mathrm{O}\right)$ (calc. 297.12). 


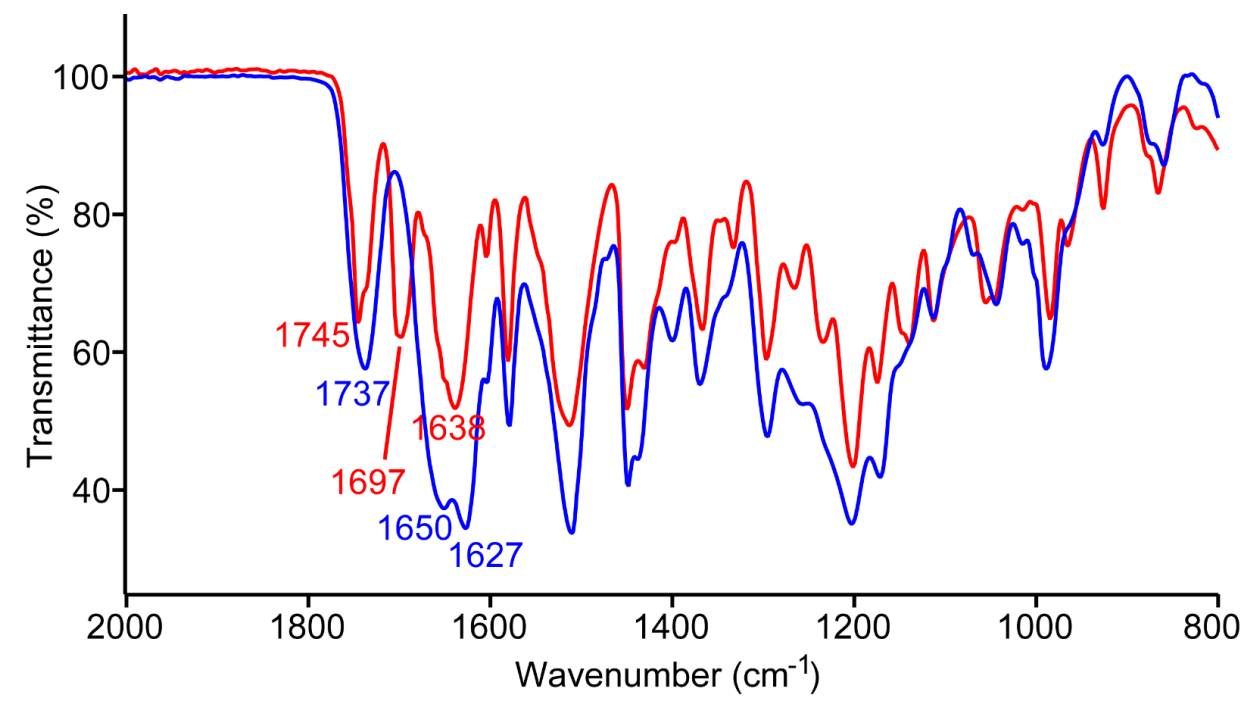

Figure S20. Comparison of solid-state FT-IR spectral features corresponding to 2c (red) and 2c $\left({ }^{18} \mathrm{O}\right.$-labeled; blue) under ambient conditions.
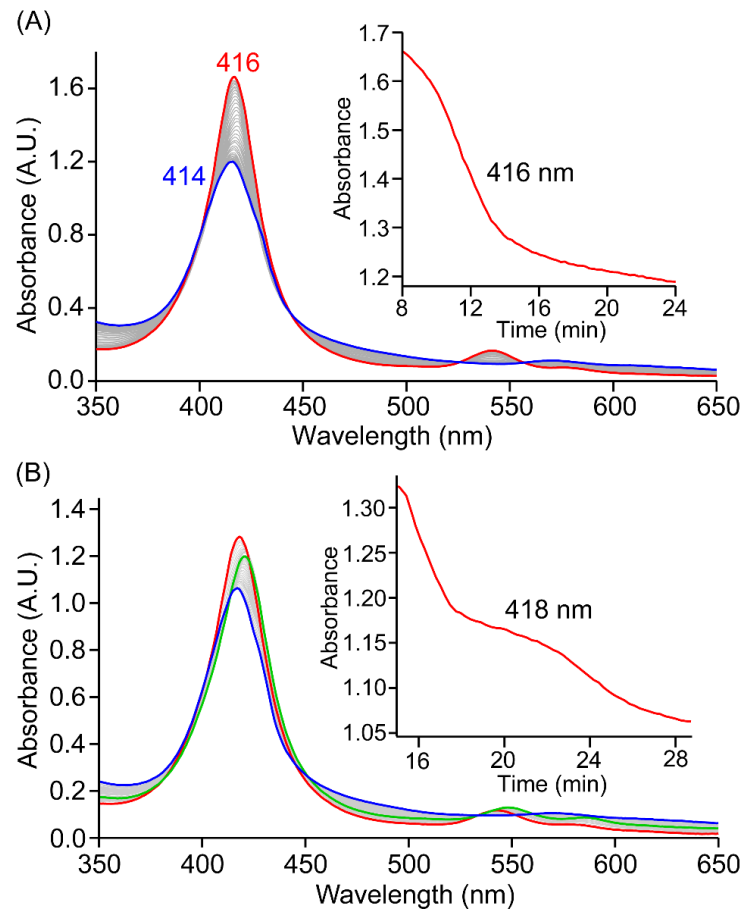

Figure S21. UV-Vis spectral changes in 9:1 DCM:THF at $-40{ }^{\circ} \mathrm{C}$, and kinetic time traces (insets)

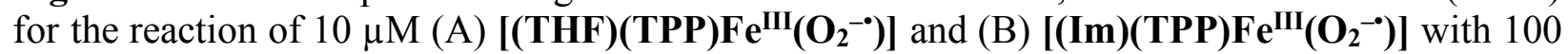
equiv of 3-methylindole. $($ Red $=$ initial ferric superoxo complex; blue $=$ final ferric product $)$. 

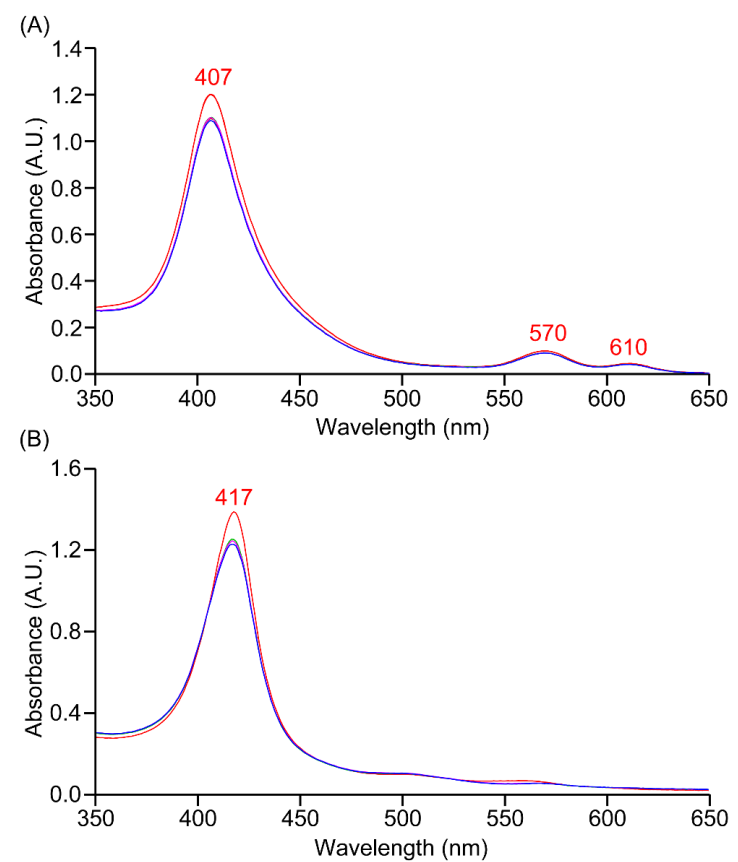

Figure S22. UV-Vis spectral changes in 9:1 DCM:THF at $-40{ }^{\circ} \mathrm{C}$, for the reaction of (A) $\left[\left\{(\mathrm{TPP}) \mathrm{Fe}^{\mathrm{IIII}}\right\}_{2}(\mu-\mathbf{O})\right]$ and (B) [(THF)(TPP)Fe $\left.\mathbf{F e}^{\mathrm{IV}}(\mathbf{O})\right]$, with 100 equiv of 3 -methylindole (Red = initial heme species; blue $=$ final spectrum after $30 \mathrm{~min})$.

(A)

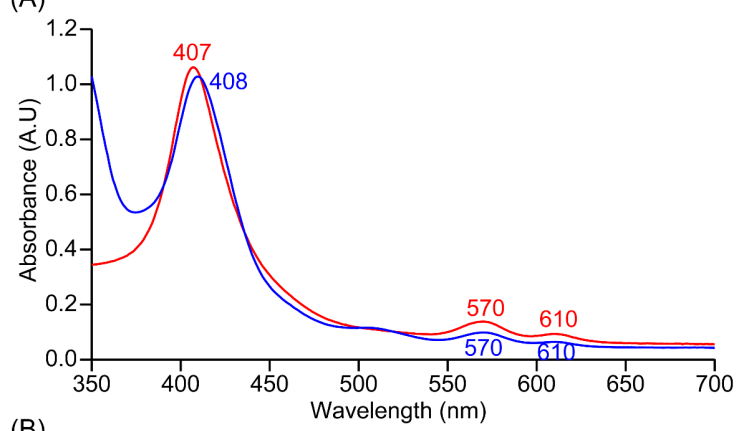

(B)

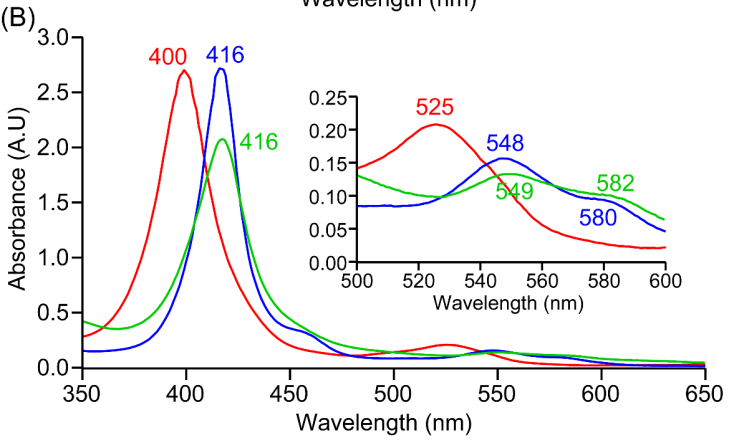

Figure S23. UV-vis spectra (in 9:1 DCM:THF at $-40{ }^{\circ} \mathrm{C}$ ) of (A) $\left[\left\{(\mathbf{T P P}) \mathbf{F} \mathbf{e}^{\mathrm{IIII}}\right\}_{2}(\boldsymbol{\mu}-\mathbf{O})\right]$ (red) and final heme product from the reaction of [(THF)(TPP)Fe $\left.{ }^{\mathrm{III}}\left(\mathbf{O}_{2^{-}}\right)\right]$with 3-methylindole (blue); (B) 'naked' [(THF) $\left.)_{2}(\mathbf{T P P}) \mathbf{F e}^{\mathrm{III}}\right] \mathbf{S b F}_{6}(\mathrm{red}),\left[(\mathrm{Im})_{2}(\mathbf{T P P}) \mathbf{F e}^{\mathrm{III}}\right]^{+}$(blue), and final heme product from the reaction of $\left[(\mathbf{I m})(\mathbf{T P P}) \mathbf{F e}^{\mathrm{III}}\left(\mathbf{O}_{2}{ }^{-0}\right)\right]$ with 3-methylindole (green); Inset shows the expanded Qband regions. 

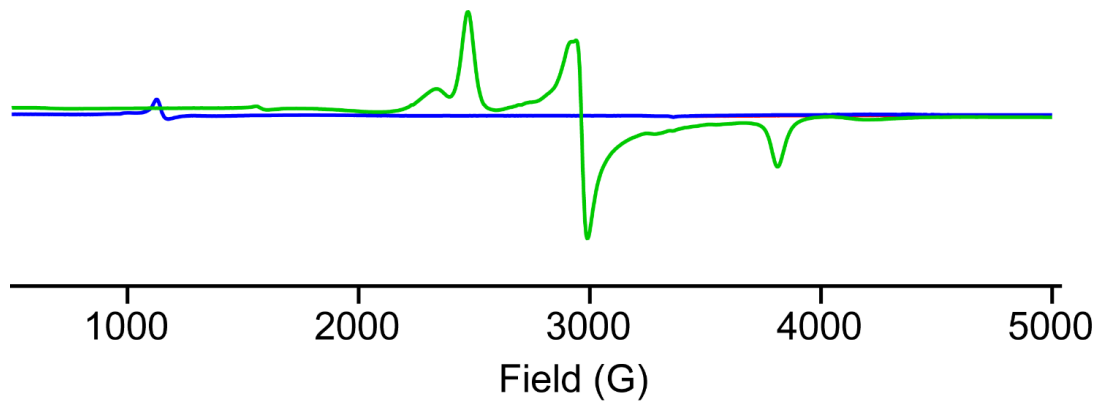

Figure S24. EPR spectral features (in frozen 9:1 DCM:THF at $7 \mathrm{~K}$ ) of the final heme product from the reaction of $2 \mathrm{mM}\left[(\mathbf{T H F})(\mathbf{T P P}) \mathbf{F e}^{\mathrm{IIII}}\left(\mathbf{O}_{2}^{--}\right)\right]$(blue) and $\left[(\mathbf{I m})(\mathbf{T P P}) \mathbf{F e}^{\mathrm{III}}\left(\mathbf{O}_{2^{-}}\right)\right]$(green) with 3methylindole. The final product in the former case, $\left[\left\{(\mathbf{T P P}) \mathbf{F e}^{\mathrm{III}}\right\}_{2}(\boldsymbol{\mu}-\mathbf{O})\right]$ is expected to be EPRsilent as observed here, and that of the latter case, $\left[(\mathbf{I m})_{2}(\mathbf{T P P}) \mathbf{F e}^{\mathrm{III}}\right]^{+}$, contains a low-spin $\mathrm{Fe}^{\mathrm{III}}$ center with $\mathrm{g}=2.8,2.3$, and $1.8 .^{1}$

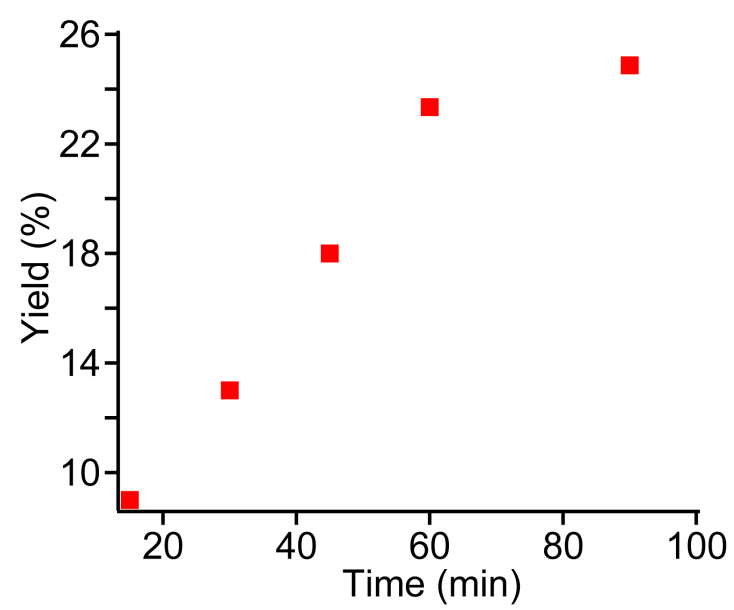

Figure S25. Formation of dioxygenated product $\mathbf{2 b}$ with time during the reaction of $\left[(\mathbf{T H F})(\mathbf{T P P}) \mathbf{F} \mathbf{e}^{\mathrm{III}}\left(\mathbf{O}_{2}^{--}\right)\right]$and 2,3-dimethylindole.

\section{References}

1. (a) Ehudin, M. A.; Quist, D. A.; Karlin, K. D. J. Am. Chem. Soc. 2019, 141, 12558-12569. (b) Ide, Y.; Murai, N.; Ishimae, H.; Suzuki, M.; Mori, S.; Takahashi, M.; Nakamura, M.; Yoshino, K.; Ikeue, T. Dalton Trans. 2017, 46, 242. 